\title{
PENELUSURAN FUNGI ENDOFIT SEBAGAI PENGHASIL SENYAWA ANTIBIOTIKA DARI DAUN NANAS (Ananas comosus (L) Meer)
}

\author{
Fitriana, St. Maryam, Tadjuddin Naid, Maryana \\ Fakultas Farmasi Universitas Muslim Indonesia Makassar \\ Email : fitriana.fitriana@umi.ac.id.
}

\begin{abstract}
A search endophytic fungi from the leaves of pineapple (Ananas comosus ( $L$ ) Merr) as a producer of antibiotic compounds will be carried out in order to obtain the endophytic fungi that have the ability to produce bioactive compounds useful as antibiotics.. Results of endophytic fungi isolates obtained six fungal isolates (IJA 1, IJA 2, IJA 3, IJA 4, IJA IJA 5 and 6), which have a different macroscopic characterization of forms, edge and elevation colonies. Isolates pure microbial fermentation results in the test antibiotic activity against some bacteria using agar diffusion test. All isolates pure fermentation results showed inhibitory activity against all bacteria in test as Bacillus subtilis, Esherichia coli, Pseudomonas aeruginosa, Salmonella thypi, Shigella dysenteriae, Staphylococcus aureus, Streptococcus mutans, and Vibrio cholerae. The inhibition of fungi isolates shown in (IJA 4) with a $26 \mathrm{~mm}$ zone of inhibition against Esherichia coli bacteria.
\end{abstract}

Keywords : Isolates of endophytic fungi, pineapple leaves, Antibiotics.

\section{PENDAHULUAN}

Mikroba endofit merupakan mikroorganisme yang berasosiasi dengan jaringan tanaman sehat yang bersifat netral atau menguntungkan. Hampir setiap tanaman tingkat tinggi memiliki beberapa mikroorganisme endofit yang mampu menghasilkan senyawa biologi atau metabolit sekunder. Bahan aktif yang dihasilkan mikroorganisme endofit ini diperkirakan memiliki kemampuan yang sama dengan bahan aktif yang dihasilkan oleh tanaman induknya.
Jamur endofit, adalah jamur yang terdapat didalam sistem jaringan tumbuhan, seperti daun, bunga, ranting, ataupun akar tumbuhan. Jamur ini menginfeksi tumbuhan sehat pada jaringan tertentu dan mampu menghasilkan mikotoksin, enzim, serta antibiotika (1).

Mikroba endofit berasosiasi dengan jaringan hidup pada tanaman. Dalam hal ini terjadi interaksi antara mikroba endofit dengan tanaman. Hubungan ini diperkirakan saling menguntungkan (simbiosis 
Penelusuran Fungi Endofit Sebagai Penghasil Senyawa Antibiotika Dari Daun Nanas (Ananas comosus ( $L$ ) Meer).

mutualisme), tanaman memberikan nutrisi untuk mikroba, lalu mikroba mentransformasi dan menghasilkan senyawa bioaktif (2).

Daun Nanas (Ananas comosus (L) merr.) berkhasiat antipiretik, antilmintik, pencahar, anti radang dan menormalkan siklus haid. Pucuk Nanas dimanfaatkan sebagai tanaman yang dapat menyembuhkan amandel, selain itu juga daunya dapat digunakan sebagai obat kencing batu, pucuk daun nanas digunakan tiga kali dalam sehari diminum tiga kali berturut-turut (3).

Daun nanas (Ananas comosus (L) Merr) mempunyai aktivitas sebagai antibakteri, kemmapuan menghambat pertumbuhan bakteri di amati ketika melakukan penelitian menggunakan infus daun nanas terhadap Ascarida gelli.

Rahman dan Sri Hartati (2014), telah melaporkan bahwa infus daun nanas memiliki aktivitas antibakteri. Dalam hal ini dibuktikan oleh kemampuan infus daun nanas dalam menghambat pertumbuhan bakteri Staphylococcus aureus (4).

Fungi endofit memiliki kemampuan untuk memproduksi senyawa bioaktif, baik yang sama maupun tidak sama dengan inangnya tetapi seringkali memiliki aktivitas biologis yang serupa dengan senyawa bioaktif yang diproduksi oleh inangnya. Hal ini menunjukkan senyawa bioatif tidak hanya didapatkan pada kandungan tanaman obat saja (5). Strober (2003), bahkan menyatakan bahwa senyawa yang dihasilkan oleh fungi endofit seringkali memiliki aktivitas yang lebih besar dibandingkan aktivitas senyawa tumbuh inangnya (6).

Berdasarkan uraian di atas, maka akan dilakukan penelitian untuk menulusuri mikroba endofit khususnya fungi endofit penghasil antibiotika dari daun Nanas (Ananas comosus (L) merr) dengan beberapa bakteri uji.

\section{METODE PENELITIAN}

\section{Bahan yang digunakan}

Bahan yang digunakan pada penelitian ini adalah Air suling, Etanol $70 \%$, Antimicrobial susceptibility test discs (Oxoid), daun Nanas (Ananas comosus (L) merr), Medium Nutrien Agar (NA), Medium Potato Dextrosa Agar Chloramfenikol (PDAC) (Difco), Medium Maltosa Yeast Broth (MYB) (Difco), Mikroba uji (Bacillus subtilis, Escherichia coli, Pseudomonas aeruginosa, Salmonella typhi, Shigella dysenteriae,Staphylococcus aureus, Vibrio colerae ,Streptococcus mutans, dan Staphylococcus epidermidis). 
Penelusuran Fungi Endofit Sebagai Penghasil Senyawa Antibiotika Dari Daun Nanas (Ananas comosus ( $L$ ) Meer).

Alat-alat yang digunakan

Alat-alat yang digunakan pada penelitian ini adalah Autoklaf (Smic Model YX-280 B), Cawan petri, Enkas, Gelas erlenmeyer $250 \mathrm{ml}$ (Iwaki Pyrex), Inkubator (Memmert), Laminar Air Flow, Neraca O'haus, Oven (Fisher), Shaker, dan Timbangan analitik.

\section{Prosedur penelitian}

Pengambilan dan Penyiapan Sampel

Sampel daun Nanas (Ananas comosus (L) merr) berasal kota Tolitoli. Sampel dibersihkan terlebih dahulu permukaan daun dari tanah yang menempel dengan menggunakan air mengalir, kemudian dilakukan sterilisasi permukaan dengan merendam daun kedalam larutan alkohol $70 \%$ selama 5 menit. Setelah itu, sampel dibilas dengan aquades steril beberapa kali.

Isolasi dan pemurnian Fungi Endofit Potongan-potongan daun Nanas (Ananas comosus (L) merr), diletakkan secara aseptis diatas medium Potato Dextrosa Agar Chloramfenicol (PDAC) padat, lalu diinkubasi selama 3-5 hari pada suhu $25^{\circ} \mathrm{C}$ atau suhu kamar. Terhadap koloni fungi yang tumbuh selanjutnya diisolasi dan dimurnikan dengan metode kuadran pada cawan petri yang berisi medium Potato Dextrosa Agar Chloramphenicol (PDA), dan diinkubasi lagi selama 3-5 hari. Pemurnian dilakukan berulang-ulang hingga diperoleh biakan yang murni atau koloni tunggal.

\section{Pemeriksaan Makroskopik}

Setiap isolat diambil satu ose, lalu diinokulasikan di atas medium PDAC dengan metode titik, kemudian diinkubasi pada suhu kamar selama $3 \times 24$ jam.Hasil dari makroskopik tersebut diamati dengan melihat tepi, elevasi, dan bentuk-bentuk koloni.

\section{Fermentasi Isolat Fungi Endofit}

Isolat fungi endofit yang telah dimurnikan diinokulasi dalam $10 \mathrm{~mL}$ medium MYB. Diinkubasi, kemudian di shaker pada kecepatan 200 rpm selama 7 hari, sehingga diperoleh fermentat.

\section{Pengujian Aktivitas Antibiotika Secara Difusi Agar}

Metode pengujian aktivitas antibiotika metode difusi agar dengan menggunakan medium NA (Nutrien Agar). Medium NA diambil sebanyak $10 \mathrm{ml}$ dan ditambahkan dengan $20 \mu \mathrm{L}$ suspensi mikroba, lalu dimasukkan kedalam cawan petri.Antimicrobial susceptibility test discs dibenamkan kedalam hasil fermentat secara aseptik kemudian diambil dan diletakkan diatas medium yang telah 
Penelusuran Fungi Endofit Sebagai Penghasil Senyawa Antibiotika Dari Daun Nanas (Ananas comosus (L) Meer).

memadat. Setelah itu, diinkubasi pada

suhu $27^{\circ} \mathrm{C}$ selama 24 jam untuk bakteri, lalu diamati dan diukur zona hambatan yang terbentuk.

\section{HASIL PENELITIAN}

\section{Pemurnian Isolat Fungi Endofit}

Tabel 1. Hasil Pemurnian Isolat Jamur

\begin{tabular}{ccc}
\hline No & Kode Jamur & Biakan Jamur \\
\hline 1 & IJA 1 & Isolat Jamur ke 1 \\
2 & IJA 2 & Isolat Jamur ke 2 \\
3 & IJA 3 & Isolat Jamur ke 3 \\
4 & IJA 4 & Isolat Jamur ke 4 \\
5 & IJA 5 & Isolat Jamur ke 5 \\
6 & IJA 6 & Isolat Jamur ke 6 \\
\hline
\end{tabular}

\section{Makroskopik}

Tabel 2. Hasil Makroskopik Isolat Jamur

\begin{tabular}{cccc}
\hline Kode Jamur & Tepi & Elevasi & Bentuk-bentuk koloni \\
\hline IJA 1 & Entire & Convex & Cirkular \\
IJA 2 & Lobate & Umbonate & Filamentous \\
IJA 3 & Undulate & Umbonate & L-Form \\
IJA 4 & Undulate & Convex & Rhizoid \\
IJA 5 & Undulate & Convex & Rhizoid \\
IJA 6 & Entire & Umbonate & L-Form
\end{tabular}

\section{Keterangan :}

$\begin{array}{ll}\text { Circular } & \text { : Tepian teratur } \\ \text { Convex } & : \text { Berbentuk kubah } \\ \text { Entire } & : \text { Tepian rata } \\ \text { Lobate } & \text { : Tepian berlekuk } \\ \text { L-Form } & : \text { Bentuk yang samar } \\ \text { Filamentous } & : \text { Seperti benang tepian menyebar } \\ \text { Undulate } & : \text { Tepian bergelombang } \\ \text { L-From } & : \text { Bentuk yang samar } \\ \text { Umbonate } & \text { : bentuk yang cembung tengah lebih menonjol }\end{array}$


Penelusuran Fungi Endofit Sebagai Penghasil Senyawa Antibiotika Dari Daun Nanas (Ananas comosus ( $L$ ) Meer).

\section{Uji Aktivitas Antibiotik dari Isolat Fungi Endofit Ambatan dari Isolat Jamur pada Daun Nanas (Ananas comosus (L) merr).}

Tabel 3. Hasil uji aktifitas antibiotika pada Daun Nanas (Ananas comosus (L) merr).

\begin{tabular}{|c|c|c|c|c|c|c|c|}
\hline \multirow{2}{*}{ No } & \multirow{2}{*}{ Bakteri } & \multicolumn{6}{|c|}{ Diameter Zona Hambatan (mm) } \\
\hline & & IJA 1 & IJA 2 & IJA 3 & IJA 4 & IJA 5 & IJA 6 \\
\hline \multirow{4}{*}{1} & \multirow{3}{*}{ BS } & 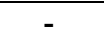 & 6 & 7 & 14 & 16 & 18 \\
\hline & & - & 7 & 7 & 13 & 16 & 18 \\
\hline & & - & 7 & 8 & 12 & 17 & 18 \\
\hline & $\mathrm{R}$ & - & 6,7 & 7,3 & 13 & 16,3 & 18 \\
\hline \multirow{4}{*}{2} & \multirow{3}{*}{ PA } & 9 & 11 & 13 & 12 & 11 & 17 \\
\hline & & 9 & 11 & 13 & 11 & 12 & 15 \\
\hline & & 9 & 11 & 13 & 11 & 12 & 16 \\
\hline & $\mathrm{R}$ & 9 & 11 & 13 & 11,3 & 11,3 & 16 \\
\hline \multirow{4}{*}{3} & \multirow{3}{*}{ SM } & 12 & 12 & 16 & 13 & 13 & 11 \\
\hline & & 12 & 13 & 16 & 14 & 13 & 13 \\
\hline & & 13 & 13 & 16 & 14 & 13 & 13 \\
\hline & $\mathrm{R}$ & 13,3 & 12,6 & 16 & 13,7 & 13 & 12,3 \\
\hline \multirow{4}{*}{4} & \multirow{3}{*}{ SD } & 1 & 14 & 11 & 12 & 13 & 16 \\
\hline & & 9 & 14 & 11 & 13 & 13 & 18 \\
\hline & & 9 & 14 & 11 & 12 & 13 & 18 \\
\hline & $\mathrm{R}$ & 6,3 & 14 & 11 & 12,3 & 13 & 17,3 \\
\hline \multirow{4}{*}{5} & \multirow{3}{*}{ VC } & 11 & 11 & 11 & 14 & 15 & 16 \\
\hline & & 12 & 1 & 15 & 14 & 15 & 16 \\
\hline & & 12 & 1 & 16 & 14 & 15 & 16 \\
\hline & $\mathrm{R}$ & 8,3 & 4,3 & 14 & 14 & 15 & 16 \\
\hline \multirow{4}{*}{6} & \multirow{3}{*}{ EC } & 15 & 17 & 29 & 26 & 21 & 19 \\
\hline & & 15 & 18 & 19 & 26 & 21 & 18 \\
\hline & & 15 & 18 & 19 & 26 & 2 & 18 \\
\hline & $R$ & 15 & 17,7 & 22,3 & 26 & 14,7 & 18,3 \\
\hline \multirow{4}{*}{7} & \multirow{3}{*}{ ST } & 1 & 1 & 11 & 14 & 15 & 16 \\
\hline & & 12 & 1 & 12 & 15 & 16 & 17 \\
\hline & & 12 & 11 & 12 & 15 & 17 & 16 \\
\hline & $\mathrm{R}$ & 8,3 & 4,3 & 11,7 & 14,7 & 16 & 16,3 \\
\hline \multirow{4}{*}{8} & \multirow{3}{*}{ SA } & 1 & 12 & 14 & 13 & 14 & 15 \\
\hline & & 11 & 13 & 14 & 14 & 13 & 17 \\
\hline & & 1 & 13 & 14 & 14 & 13 & 16 \\
\hline & $R$ & 4,3 & 12,7 & 14 & 13,7 & 13,3 & 16 \\
\hline
\end{tabular}

\section{Keterangan :}

R : Rata-Rata

IJA 2 : Isolat Jamur 2

IJA 4 : Isolat Jamur 4

IJA 6 : Isolat Jamur 6

PA : Pseudomonas aeruginosa

SD : Shigella dysenteriae

EC : Escherichia coli

SA : Straphylococcus aureus
IJA 1 : Isolat Jamur 1

IJA 3 : Isolat Jamur 3

IJA 5 : Isolat Jamur 5

BS : Bacillus subtilis

SM : Streptococcus mutans

VC : Vibrio cholera

ST : Salmonella thypi

\section{PEMBAHASAN}

Sampel yang digunakan pada penelitian ini adalah daun Nanas
(Ananas comosus (L) merr) sebagai salah satu sumber penghasil fungi endofit. Penelitian di awali dengan 
Penelusuran Fungi Endofit Sebagai Penghasil Senyawa Antibiotika Dari Daun Nanas (Ananas comosus ( $L$ ) Meer).

mengisolasi fungi endofit pada daun Nanas dengan menggunakan difusi agar.

Daun nanas (Ananas comosus (L) merr) yang di ambil berasal dari tanaman yang sehat untuk menghindari adanya fitopatogen didalam jaringan tanaman. Permukaan duan dibersihkan terlebih dahulu dari tanah yang menempel dengan menggunakan air mengalir, kemudian dilakukan sterilisasi dengan merendam air kedalam alkohol dan dibilas menggunakan aquadest steri beberapa kali.

Setelah sampel disterilisasikan, dilakukan isolasi fungi endofit pada sampel dengan cara di tempelkan potongan Daun nanas (Ananas comosus (L) merr) ke dalam medium Potato Dextrosa Agar Cloramphenicol (PDAC) yang telah memadat, kemudian di inkubasi pada suhu kamar selama 3×24 jam. Koloni jamur yang menunjukan zona hambatan, lalu digoreskan pada medium miring PDAC dan diinkubasi selama 3×24 jam pada suhu kamar. Tujuan penggunaan kloramfenikol adalah untuk mencegah pertumbuhan bakteri pada medium. Selain itu, dalam penggunaanya harus masih segar karena kloramfenikol tidak tahan terhadap suhu tinggi dari pemanasan maupun pensterilan dari medium.

Berdasarkan hasil isolasi, diperoleh enam isolat yang memiliki pencirian (bentuk, koloni dan warna) yang berbeda-beda. Selanjutnya, isolat Daun nanas (Ananas comosus (L) merr) dimurnikan dengan metode Quadran streak. Metode ini bertujuan untuk memperoleh isolat tunggal. Metode quadran berpola goresan yang berbeda, yaitu dibagi empat daerah. Daerah pertama, merupakan goresan awal sehingga masih banyak mengandung sel mikroorganisme. Goresan selanjutnya, dipotong atau disilangkan dari goresan sebelumnya sehingga jumlah koloninya semakin sedikit dan akhirnya terpisah-pisah menjadi koloni tunggal. Isolat murni yang diperoleh, dibuat kultur dalam medium agar dan digunakan sebagai stok.

Hasil yang diperoleh selanjutnya, di uji secara makroskopik meliputi bentuk, tepi dan elevasi koloni. Selanjutnya dilakukan proses fermentasi. Pada proses fermentasi, medium yang digunakan adalah Maltosa Yeast Broth (MYB), lalu di kocok dengan menggunakan Shaker kecepatan 200 rpm selama 7×24 jam. Tujuan dilakukan fermentasi selama 7x24 jam agar selama difermentasi, 
Penelusuran Fungi Endofit Sebagai Penghasil Senyawa Antibiotika Dari Daun Nanas (Ananas comosus ( $L$ ) Meer).

isolat fungi endofit pada Daun nanas (Ananas comosus (L) merr) akan mencapai fase stasioner dan menghasilkan metabolit sekunder berupa antibiotika. Adapun alasan penggunaan MYB, karena medium ini merupakan media cair yang mengandung ekstrak yeast sebagai sumber protein, maltosa dan dektrosa sebagai sumber karbon, dan pepton sebagai sumber asam amino yang dibutuhkan dalam pertumbuhan, sintetis sel, dan keperluan energi dalam metabolisme mikroorganisme.

Fermentat yang diperoleh, Ialu di uji aktivitas antibiotikanya dengan metode difusi agar, menggunakan antimicrobial susceptibility tes discs terhadap beberapa bakteri uji, yaitu Bacillus subtilis, Pseudomonas aeruginosa, Streptococcus mutans, Shigella dysenteriae, Vibrio cholerea, Escherichia coli, Salmonella thypi dan Straphylococcus aureus. Metode ini dengan berdasarkan sifat-sifat patogeniknya yang diharapkan isolat fungi endofit Daun nanas (Ananas comosus (L) merr) mampu mengahambat pertumbuhan mikkroba patogen tersebut.

Hasil dari uji aktivitas antibiotika ini merupakan aktivitas yang berbedabeda dari setiap isolat. Hal ini dapat dilihat dari diameter zona hambat yang terbentuk pada saat pengujian aktivitas antibiotika yang telah dilakukan.

Adapun hasil pengukuran zona hambat dari isolat jamur yang menunjukan bahwa, Isolat jamur ke 1,2,3,4,6 (IJA1, IJA 2, IJA 3, IJA 4, dan IJA 6) berdasarkan diameter zona hambatnya sangat aktif menghambat pertumbuhan Escherichia coli dengan diameter masing-masing sebesar 15 $\mathrm{mm}, 17,7 \mathrm{~mm}, 22,23 \mathrm{~mm}, 26 \mathrm{~mm}, 18$ $\mathrm{mm}$. Selanjutnya pada isolat jamur ke 5 mampu menghambat Salmonella thypi, dimana diameter zona hambat yang terbentuk adalah $16 \mathrm{~mm}$. Dari hasil di atas dapat disimpulkan bahwa, penghambatan terbesar ditunjukan pada isolat jamur (IJA 4) dengan zona hambat sebesar $26 \mathrm{~mm}$ terhadap bakteri Escherichia coli, dimana bakteri Escherichia coli merupakan bakteri gram negative.

\section{KESIMPULAN}

1. Daun nanas (Ananas comosus $(\mathrm{L})$ merr) mengandung fungi endofit penghasil antibiotika dengan penghambatan terbesar pada bakteri Escherichia coli dengan zona hambat $26 \mathrm{~mm}$.

2. Fungi endofit dari sampel Daun nanas (Ananas comosus $(\mathrm{L})$ merr), mampu menghambat bakteri Bacillus subtilis, Pseudomonas 
Penelusuran Fungi Endofit Sebagai Penghasil Senyawa Antibiotika Dari Daun Nanas (Ananas comosus ( $L$ ) Meer).

aeruginosa, Streptococcus mutans,

Shigella dysenteriae, Vibrio

cholera, Escherichia coli,

Salmonella thypi dan

Straphylococcus aureus.

\section{DAFTAR PUSTAKA}

1. Lingga R. Uji Nematisidal Jamur Endofit Tanaman Padi (Oryza sativa L.) Terhadap Nematoda Puru Akar (Meloidogyne Sp.). (Skripsi). Medan: Universitas Sumatera Utara, 2009.

2. Aisyah AMG. Skrinning Mikroba Endofit Penghasil Antimikroba dari Tanaman Temu Putih (Curcuma zedoria (Berg) Roscoe) Terhadap E. Colli, Candida albicans, dan A. Niger (Skripsi). Mahasiswa Fakultas Matematika dan IImu Pengetahuan Alam. Institut Sains dan Teknologi Nasional Tumbuhan Berguna Indonesia (Edisi 1). Jakarta:Yayasan Sarana Wara Jaya, 2004.
3. Sugeng HS, B. Sinaga, B. Winarso, E. Handayani, I. Karim, Purwanto, Suparno, dan Triyanto. Pembibitan dan penanaman. Dalam S.A. Yomo, S. Benny, Zulfahmi, W. Putut, Suharyono, dan W. Bambang (Penyunting). Pedoman praktis budidaya nanas di PT Geat Giant Pineapple Terbangi Besar Lampung Tengah, 2008.

4. Rahman dan Srihartati. Uji aktivitas infus daun nanas terhadap bakteri Sthaphlococcus aureus (tesis). Gorontalo: Universitas Negeri Gorontalo, 2014.

5. Prihatiningtias WM dan Sri W. Aktivitas Antibakteri Fungi Endofit dari Thievalia polygonoperda, Isolat dari Tumbuhan Akar Kuning (Fibraurea chloroleuca Miers). Majalah Obat Tradisional 2011;16.

6. Strobel GA. Endophytes as Sources of Bioactive Products. Review of Microbiology 2003;1. 